\title{
The Development of Thematic Integrative Based Learning Material for Fifth Grade Elementary School
}

\author{
Qoumi Ghonin Hamidah ${ }^{1}$, Siti Sutarmi Fadhilah'², Bambang Wasito Adi ${ }^{3}$
}

\begin{tabular}{l} 
ARTICLE INFO \\
\hline Article History: \\
Received 14.07.2018 \\
Received in revised form \\
17.09.2018 \\
Accepted \\
Available online 01.01.2019
\end{tabular}

\begin{abstract}
The purpose of this research is to produce thematic integrative based learning material theme "Lingkungan Sahabat Kita" for fifth grade of elementary school in Sragen. This research belongs to Research and Development (R\&D), which consists of three stages, namely: (1) preliminary study; (2) development study; (3) product's effectiveness test. The result of the research showed that the developed learning material was appropriate and effective to be used in the learning process. The appropriateness of the learning material was shown by the statement of "very good" by the language experts with the percentage of $87,5 \%$, the statement of "good" by material experts with the percentage of $77,5 \%$, and the statement of "very good" by media experts with the percentage of $89,35 \%$. The effectiveness was proved by t-test which had t computation as 3.453 with the probability score 0.001 . Probability score $<0.05$, thus based on the mentioned criteria above, H0 was rejected. It means that there is prior score difference between experimental group and control group. Based on the explanation above, it can be concluded that the experimental group has better score of theme "Lingkung an Sahabat Kita" than control group.
\end{abstract}

(C) 2018 IJERE. All rights resenved

Keywords:

The development, Learning Material, Thematic, Integ rative .

\section{INTRODUCTION}

Indonesia has some educational curriculum developments. In the educational year of 2013/2014, there was a curriculum change from Kurikulum Tingkat Satuan Pendidian (KTSP) changed into Curriculum 2013. There were some factors as bases for curriculum 2013 development, namely: First, future challenges include globalization, living environment, IT innovation, science and technology convergence, and economics based knowledge. Second, future competencies, include communication ability, critical and clear thinking ability, moral problem consideration ability, becoming effective citizen ability, and different views understanding and tolerance ability. Third, arising social phenomenon like engages in a gang fight, drugs, corruption, plagiarism, cheating on exams, and social unrest. Fourth, public perception which judge that the recent education too much focuses on cognitive aspect, students' burden is too weight, and less of characteristics content (Trianto, 2015: 4). The occurrence of curriculum development in all formal educational stages called as Curriculum 2013, make the elementary school educational holder should follow the curriculum changes.

One of the important things in Curriculum 2013 is learning material. Theme based learning material considered as all of the resources (information, means, or texts) which are arranged systematically, which present the whole figure of the competencies going to be mastered by the students through learning process which encourage students' involvement actively and fun. In which it does not only encourage the students in learning to know, but also learning to do into learning to be, and learning to live together, and also holistic and authentic, with the purpose of planning and examining the learning implementation (Prastowo, 2013: 199).

The learning material in Curriculum 2013 has been designed systematically, interestingly, and conditioned with students' needs, but Curriculum 2013 focuses on curriculum content simplified and the integration of integrative theme based learning (especially for elementary school). It, of course will affect in providing new learning material. Therefore, it becomes the important source in supporting learning process. The present of learning material now adays becomes the connection between teacher and students where the teacher has a role as facilitator, thus the use of learning material can bridge the problems of students' receiving limitation and teacher's ability in managing learning in the classroom. The learning material in the form of learning book Curriculum 2013 should be fulfilled appropriateness test in order it can be used as it is. In the effort as optimizing the implementation of Curriculum 2013, it needs the development of studen ts' book to find out the content of Curriculum 2013 which contain integrative theme based, scientific approach, and authentic assessment.

\footnotetext{
${ }^{1}$ Corresponding e-mail: qoumihasan@gmail.com, orcid.org/0000-0003-3139-3364, 1,2,3 Sebelas Maret University
} 
Hamidah,Q.G., Fadhilah,S.S. \& Adi,B.W.(2019). The development of thematic integ rative based learning material for fifth grade elementary school. International Journal of Educ ational Research Review, 4 (1), 8-14.

Thematic integrative based learning considered as learning approach which integrates various competencies from various subject matters into various themes. Web \& Pearson (2012:19) state that the first activity in thematic based learning is analyzing the chosen theme. A thematic model considered a unity of various themes which contains learning ideas and integrates some topics. The teacher as educator should provide activities which are relevant and contextually meaningful for the students.

Thematic integrated based learning model stresses more on the students centered learning. It means the model involves the students in the teaching and learning process or direct the students to actively involved in the learning process. Besides that, thematic integrative based learning also gives chances for the students to connect between experiences and knowledge owned by the students in order to ease them in solving the problems and fulfilling their needs of knowledge (Huber \& Hutching, 2008: 1). Randle (2010: 85) adds integrated thematic instruction-based curricula stresses the integration of all disciplines to present student with learning experiences that are based on real-w orld application and structured to encourage higher-order learning.

One of the important components in Curriculum 2013 is learning material. Thematic based learning material is considered as all of materials (information, means, texts) arranged systematically, which show or explore a whole of competencies going to be mastered by the students through learning process to encourage the students to be actively involved and exciting. It means, it does not only encourage the students learning to know but also learning to do into learning to be and learning to live together, and holistic and authentic with the purpose of planning and learning implementation exploration (Prastowo, 2013: 199).

One of the factors to determine students' success in utilizing the text book is by determining the quality of the text book. In measuring the quality of the text book, one should be paying attention the importance aspects such as content's appropriateness with the curriculum, truthful content, systematics presentation, functional language used. If the text book used by the students have low appropriateness between the content and curriculum it will lead to the expected competency will be hard to acquire (Novianto\&Mustadi, 2015).

In addition, if it has misconception, it will result in understanding differences between the students and the book's what actually mean. Thus, it will affect the students' thinking pattern in receiving the next knowledge. In result, it will be hard to straighten up it to the right path since the knowledge which has been integrated in their head will stay permanently. It can happen if the teacher tends to acknowledge that all the contents of the text book. It also will affect in whether the students' achievement increase or not. Novianto\&Mustadi, 2015).

The problem a rising both in learning process or outside the learning are: (1) innovative learning model and method implemented by the teacher were not been conducted in optimum state, there were some teaching steps missed; (2) students' involvement in learning process was low, they tend to be passive; (3) the students were not used to with thematic based learning; (4) there is no practical learning material to be used as references and learning sources both for the teacher and students; (5) wasted teacher's time in finding out the material which is suitable with the basic competence since the text book considered as learning material source is still separated. It is not integrated in one theme, thus the teacher should choose thoroughly; (6) the students' low achievement.

The purpose of this research is to produce learning material which is appropriate with teacher's and students' needs and appropriate with the recent curriculum in Indonesia, Curriculum 2013.

\section{METHOD}

This research was research and development. Sukmadinata (2012: 57) state that in simple, there are three stages in research and development, namely: (1) preliminary study which examines theories and observes the provided product; (2) conduct product's development processing or new activity program; (3) validate the product or new program.

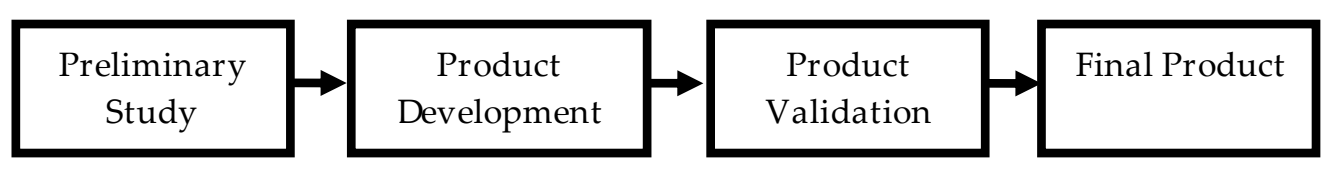

Figure 1. The Stages of Learning Material Development 
Hamidah,Q.G., Fadhilah,S.S. \& Adi,B.W.(2019). The development of thematic integ rative based learning material for fifth grade elementary school. International Journal of Educ ational Research Review, 4 (1), 8-14.

The data collecting techniques used in this research are observation, product evaluation, and interview. The research was conducted in SD N Peleman 1, SD N Tempelrejo 1, SD N Pungsari 1, SD N Karangasem 2, SD N Bonagung 2 which involved some teachers and students. The data analysis was conducted by using interactive model by Miles and Hubberman and in pair $\mathrm{t}$-test.

\section{RESULT}

This research belonged to research and development which had objectives as follow: (1) to find out the need of thematic integrative based learning material in the form of textbooks for fifth grade elementary school entitled theme "Lingkungan Sahabat Kita"; (2) to find out the development of thematic integrative based learning material in theme "Lingkungan Sahabat Kita"; (3) to find out the effectiveness of the thematic integrative based learning material in theme "Lingkungan Sahabat Kita".

\section{The Need of Thematic integrative Based Learning Material in Theme "Lingkungan Sahabat Kita" of Fifth Grade Elementary School in Sragen}

In developing learning material, it needs to conduct some stages as mentioned by Ranjit (2012:2) that stages-stages needed to conduct in developing learning material are identify the need of problem, analyze the problem, select the topic, select writing format, select content arrangement, edit, and revise in preliminary research to find out the need of new learning material.

The analysis result of that new learning material which was conducted for 7 teachers in 6 elementary schools were: (1) the learning material which is appropriate with Curriculum 2013's aspects, namely implementing thematic integrative based scientific approach and authentic assessment; (2) the need additional learning material which is still in line with the teacher's book means that it is in line with determined basic competence; (3) the additional learning material can also motivate students in learning process; (4) the material should be more complete than the old learning material and more practical; (5) the need of exercises to evaluate; (6) the price of the additional learning material should be achievable thus the students are able to buy and use it at home; (7) the language used in the learning material should be readable by the students; (8) the old learning material did not have glossaries, thus the new one should has it in order to ease the students in learning new terms.

Meanwhile, the result of the interview of the students from some elementary school showed that: (1) the content of the material is complete; (2) the material is easy to be understood; (3) it has relevant illustration with the material or suitable for students' development (colorful); (4) the writing is easy to be read and be understood by the students; (5) there are many new, unique, and useful things; (6) the learning material can be brought home and be taught at home; (7) there are real life pictures. Based on the result of the preliminary study above, it found the lack of the learning material in the area of presented material.

In the point 1 of the teacher interview, it is said that there was a need of learning material which was suitable with Curriculum 2013's aspects. Kemendikbud (2013:18) explains some new and important things in Curriculum 2013 namely: (1) the curriculum based on scientific approach, thus the learning process stresses on observing, asking, reasoning, trying, and communicating; (2) as for elementary school level the theme is integrated thematic based, there is no subject matter instead of themes in which integrates various subject matter turned into students' competencies; (3) the competencies going to achieve should be balance between behavior, skill, and knowledge through holistic and fun learning; (4) the learning process stresses on the aspects of behavior, knowledge, and skill with the assessment based on test and portfolio complementary each other; (5) the number of subject matter from ten changed into six.

The basic mentioned above become the reason why thematic integrative based learning needed to be developed. The result of the research conducted by Ariyani and Wangit (2016) also shows that the teachers really need another learning material based on Curriculum 2013 beside the one provided by Kemendikbud, since it is limited, thus the teachers still need supporting learning material which interact students' interest, encourage to be creative and have various activities.

\section{The development of thematic integrative based learning material for theme "Lingkungan Sahabat Kita"}

The development of thematic integrative based learning material was conducted based on the literature study, preliminary study, and exploration stage. The development of thematic integrative based learning material still use the guidance from the textbook provided by Kemendikbud in which it still being suited with the standard competence and basic competence of the teacher book. It is in line with Prastowo 
Hamidah,Q.G., Fadhilah,S.S. \& Adi,B.W.(2019). The development of thematic integ rative based learning material for fifth grade elementary school. International Journal of Educ ational Research Review, 4 (1), 8-14.

(2015:170) who says that the rule in developing learning material is based on present national education curriculum, oriented on process skill, and give clear integration among disciplines. The material packing is packed on theme based since it is suited with the main learning material. In thematic based learning, the presence of learning material has the use of helping to carry out the curriculum, becoming teacher's guidance in determine the learning method, giving knowledge both for the students and teacher.

The beginning arrangement of the prototype is started by collecting the basic competencies from the book provided by Kemendikbud, collecting materials, making material map, and arranging the materials into a book. The prototy pe itself has three parts as the beginning, main, and end. For the beginning part, the prototype contains acknowledgement, the preface, and table of content. The beginning part (front cover of the learning material, front page cover, acknowledgement, core competencies of fifth grade, basic competencies of thematic integrative based learning for fifth grade, the instruction of the theme based book usage, table of content); main part (the content of the thematic integrative based learning material which has 3 sub-themes ended up on evaluation); end part (bibliography, book composer's biography).

\section{Prototype Validation and Revision}

The development of the learning material in this research was started from prototype planning, and then conducted product validation by involving experts of language, media, and material. According to Abidin (2016: 275) who explains that experts opinions are really needed to gain conceptual opinion in perfecting model theoretical base.

The result of the language expert showed the score percentage of $87,5 \%$ and it belonged to the category "Very Good" and be ready to be used but still need some revision based on the advice from the language experts. The parts which considered as enough are: (1) correct language spelling; (2) correct grammar; (3) correct sentence pattern; (4) correct spelling. Based on the result above, the revision is conducted for the considered enough parts.

Based on the validation of the material experts, the score percentage $\mathrm{w}$ as $77,5 \%$ and belonged to the category of "Good" and be ready to be used but still need revision based on the material experts' advice. Meanwhile, the parts considered as "enough" are: (1) the accuracy of terms using; (2) the accuracy of symbols; (3) the accuracy of literature references; (4) the most recent literature; (5) encouraging aspects for students to raise questions; (6) the consistency of presented systematic; (7) the examples of material activity; (8) glossaries; (9) the accuracy of used case.

As for the media parts, it got score percentage of $95,8 \%$ with the category of "Very Good". In the preliminary it got the percentage of $91,6 \%$ with the category of "Very Good". The text matter got $95 \%$ with the category of "Very Good". And post-liminaries got 75\% with the category "Good". From the validation of those aspects, it can be concluded that the product are ready to be used. Meanwhile, the aspects considered as "enough" are: (1) illustration; (2) color and object size; (3) creativity and dynamics; (4) book cover; (5) activity title, subtitle.

\section{Limited Try-Out}

Like as other development stages, there was try-out in the form of limited try-out and board try-out. Sukmadinata (2016: 185) explains that limited try-out means conduct try-out at the school in small scale with limited numbers of teacher. In this research, limited try-out was conducted in SD N Pungsari 1 by taking consideration the opinion of 1 fifth grade teacher (Teacher DL) and 20 students. The procedure in limited try-out are: (1) giving the pre-test to the students; (2) distribute the thematic integrative based learning material to the students; (3) teacher uses new learning material in the learning process for a week or meeting 6; (4) considering the opinion of the teacher through interview and questionnaire assessment; (5) considering students' opinion through interview; (6) taking students' evaluation result from post-test after meeting 6.

The result of Teacher DL evaluation through questionnaire about learning material's appropriateness, it considered as very good with the percentage of $88 \%$, while from the students, it got $95 \%$. The advices from the Teacher DL are: (1) recheck thoroughly for the writing in the text. Meanwhile, the result of the students' interview are: (1) the content of the material is appropriate with the potency going to be achieved by the students; (2) the book is encouraging enough for the students to be interested; (3) language used is simple and easy to be understood; (4) interesting book presentation; (5) the book gives knowledge about the 
Hamidah,Q.G., Fadhilah,S.S. \& Adi,B.W.(2019). The development of thematic integ rative based learning material for fifth grade elementary school. International Journal of Educ ational Research Review, 4 (1), 8-14.

importance to maintain the environment. Thus, it can be said that the result of the try-out in this development process there is mistake to revise in the form of rechecking the writing in the texts.

From this point on, some revision w as conducted since it was very important to perfect the learning material as stated by Depdiknas (2008: 10) who said that learning material considered as good if it fulfill the criteria as follow: (1) stimulate reading interest; (2) written and arranged to be used by the students; (3) explain the objectives going to be achieved; (4) arranged based on flexible learning pattern; (5) the structure is based final competency going to be achieved; (6) focus on students' chance to practice; (7) accommodate learning difficulty of the students; (8) give summary; (9) writing pattern (communicative language) and semi-formal; (10)presented in the instructional process; (11) have mechanism of collecting students' feedback; (12) present learning instruction, thus by revising all aspects acquired from limited try-out, it will result in good learning material.

\section{Board Try-Out}

Development stage after limited try-out is board try-out. According Sukmadinata (2016: 186) board tryout means try-out conducted with the sample of school and more teachers. Based on the definition above which stated that the schools used in board try-out are SD N Bonagung 2 and SD N Peleman 1 in Sragen by taking 41 students and 2 teachers as learning material users. The stages in board try-out are: (1) give pre-test for the students; (2) distribute integrated thematic based learning material for the students; (3) the teachers use new learning material and old learning material in the learning process for a w eek or 6 meetings; (4) take advice from the teachers through interview and questionnaire assessment; (5) take students' opinion through interview; (6) take students' evaluation result from post-test after meeting 6.

According to the evaluation result, the differences of pre-test and post-test $w$ ith in pairs t-test between pre-test score and post-test score was 71.68, while post-test 77.15. It means that there is increase in average score. The evaluation result statistically showed the $t$ computation of 6.355 with the probability score 0.000.probability score $<0.05$ means there is significant improvement of learning achievement for theme lingkungan sahabat kita in the board try-out.

As for the questionnaire given to Teacher $S$ and SR as homeroom of the fifth grade, the point which stated in the limited try-out based on teachers' responses and students' responses, it can be concluded that in general thematic integrative based learning material by the teacher and students are very good with the percentage $86 \%$. From the result above, it needs revision on the parts which is considered as enough that is for the word mistakes.

The result of the interview of Teacher S and Teacher SR both of them give opinion about rechecking the dictions. As for the others, the learning material is appropriate and can be used in the next stage. Meanwhile, the opinion of the 41 students about the additional learning material (prototype) resulted in: (1) the book has presented the daily life problems; (2) the book has made the students interested; (3) the language used has been simple and easy to be understood; (4) interesting book's display. The result of the interview from teachers, students, and teachers' questionnaire resulted in revision. And then the thematic integrative based learning material being tested the effectivity, while for the comparison of pre-test and post-test SD N Bonagung 2 and SD N Peleman 1, each of them has improvement after using thematic integrative based learning material.

\section{Learning Material Effectiveness Validation theme "Lingkungan Sahabat Kita"}

The result of the effectiveness validation by implementing experiment method was started by normality test, homogenity test, and the last was balancing test. The first stage was normality test which is to prove that population of the experiment class and control class were distributed normally. And then, homogen eity test to find out wether the sample from control class and experiment class have the same variant or homogeneous. The last balancing test to find out the initial capability of each class. Based on the result of the tests, the difference betw een experiment and control class by implementing $t$-test, it got the experiment class average score of 77.148, while the average of control class was 72.15. If it was seen from the average score, the experiment class had better score than control class, since it has higher score. Moreover, the result of statistical computation the $t$ computation was $3.784 \mathrm{with}$ the probability 0.001 . The probability score $<0.05$ thus based on the criteria mentioned above, $\mathrm{HO}$ was rejected. It means there is initial score difference 
Hamidah,Q.G., Fadhilah,S.S. \& Adi,B.W.(2019). The development of thematic integ rative based learning material for fifth grade elementary school. International Journal of Educ ational Research Review, 4 (1), 8-14.

between experiment class and control class. Based on the explanation above, it can be concluded that experiment class has better result compared to the control class for theme "Lingkungan Sahabat Kita".

\section{CONCLUSION}

The steps in developing this learning material combine between development steps proposed by Gall and Sukmadinata. The development steps proposed by Borg and Gall defined as developing steps which consists of ten steps, namely: 1) research and prior information colletion;2) planning; 3) developing product's prototype;4) prior tryout; 5) product's revision; 6) field tryout; 7) product's revision;8) field tryout; 9) final product; 10) dissemination and implementation. Meanwhile, the developing steps proposed by Sukmadinata Sukmadinata (2012: 57) are 1) prior study, analyzing the theories and examining the recent product; 2 ) conducting product' development or new program activity; 3 ) testing or validating the product or new program activity.

The combination form of developing steps in this research is managed with researcher's ability. Meanwhile, the developing steps is divided into three parts, namely: (1) prior study (literature study and field study); (2) development study which consists of a) designing the prior product (prototype) considering the needs of both teacher and students; $b$ ) designing validation (experts' judgment) based on produces prototype; c) product's revision; d) limited tryout; e) product's revision based on experts' judgment; f) broad tryout; g) product's revision (experts' judgment) and conducting revision until the product is ready to be experimented for effectiveness test; 3) product's effectiveness test, by conducting experimental test in the form of comparing between pretest and posttest score of the controlled class (using old learning material) and experimental class (using new learning material).

The process of developing learning material is based on observation about the weaknesses of the old learning material. The aspects being examined of the old learning material are 1) the appropriateness of material and basic competence; 2) the appropriateness of students' age; 3) material completion with the students' needs; 4 ) the appropriateness of the material and sub theme. In addition, in the interview process with the teacher and students, the researcher finds that: 1) the material has been appropriate with the students; 2) the completion of the material in the students' books is still less complete, 3 ) the material has been appropriate with the sub theme.

From those four aspects above, it can be found that there is lack of material completion. The students' book provided by Kemendikbud becomes the only one source in Curriculum 2013 learning process. Unfortunately, the material in the students' books is not enough. Learning material becomes the important need a learning process. According to Abidin (2016: 263) material has functions as teacher's guidance in learning direction, students' guidance in the learning process. Considering the importance of learning material's role above, a developing new leaning material based on integrative theme based being conducted. Thus, the learning material can be used as learning supplement since the weaknesses of the theme based book provided by the government.

This study produced products in the form of integrative thematic-based textbooks for the fifth grade elementary school entitled theme "Lingkungan Sahabat Kita". Based on the results of the study concluded that the textbook developed in this study is valid and beneficial in learning in elementary schools. This can be seen from the result of the language experts showed the score percentage of $87,5 \%$ and it belonged to the category "Very Good", based on the validation of the material experts, the score percentage was $77,5 \%$ and belonged to the category of "Good" and from the media parts, it got score percentage of $89,35 \%$ with the category of "Very Good".

Based on the research above, it can be concluded that the result of the experiment test showed that learning material which is implementing thematic integrative based improved students' achievements. Thematic integrative based learning material increased students' achievement proved by the pre-test score from 70,74 into 77,14 . From this point on, the comparison of post-test score between control class and experiment class proved that the learning in which implementing thematic integrative based learning material is more effective to be used as additional material for the students.

Based on the conclusion above, the researcher proposes suggestions which can be used as inputs for the next researchers to develop sources related to elementary school learning material. It show ed that there are many more things to be develop in Curriculum 2013. The other research and developments can be the solution in educational worlds especially for elementary school which is gra dually getting the revison from 
Hamidah,Q.G., Fadhilah,S.S. \& Adi,B.W.(2019). The development of thematic integ rative based learning material for fifth grade elementary school. International Journal of Educational Research Review, 4 (1), 8-14.

the government. The development of course needed to be completed with the prior studies in schools in order it can be more rigid in finding out the weaknesses, thus it can develop in the maximum state.

\section{REFERENCES}

Abidin, Y.( 2016). Desain sistem pembelajaran dalam konteks kurikulum 2013. Bandung: Refika Aditama.

Ariyani, Y. \& Wangid ( 2016). Pengembangan Bahan Ajar Tematik-Integratif Berbasis Nilai Karakter Peduli Lingkungan dan Tanggung Jawab. Jurnal Pendidikan Karakter, Tahun VI (1).

Departemen Pendidikan Nasional (2008). Pengembangan Bahan Ajar dan Media. Jakarta: Departemen Pendidikan Nasional.

Huber, M.T. \& Hutchings, P. (2008). Integrative learning: Mapping the terrain. International Journal for The Scholarships of Teaching \& Learning, 2, 14-20.

Kemendikbud (2013). Kurikulum 2013 Tanya Jawab dan Opini. Jakarta: Kementrian Pendidikan dan Kebudayaan RI.

Kumar, R.( 2010). Research Metodology: A Step by Step Guide for Beginners. London: Sage Publication.

Novianto, A \& Ali, M. (2015). Analisis Buku Teks Muatan Tematik Integratif, Scientific Approach, dan Authentic Assessment Sekolah Dasar. Jurnal Kependidikan, 45 (1) 1-15.

Prastowo, A.(2013). Pengembangan Bahan Ajar Tematik. Yogyakarta: Diva Press.

Prastowo, A. (2014). Pengembangan Bahan Ajar Tematik. Jakarta: Prenadamedia.

Randle, I. (2010). The measure of success:Integrated thematic instruction. The Clearing House, 71, 85-87.

Sukmadinata, S. N. (2012). Metode Penelitian Pendidikan. Bandung: Remaja Rosdakarya.

Sukmadinata, S. N. (2016). Metode Penelitian Pendidikan. Bandung: Remaja Rosdakarya.

Webb, P.I., \& Pearson, P.J. (2012). Creative unit and lesson planning through a thematic/integrated approach to teaching games for understanding (TGfU). New Zealand Physical Educator, 45(3), 17-22. 